\title{
CĂN NGUYÊN VI SINH VẬT GÂY VIÊM PHỔI Ở TRẺ 2 THÁNG ĐẾN 5 TUỔI TẠI BÊ̂NH VIỆN TRUNG ƯƠ'NG THÁI NGUYÊN
}

\section{TÓM TẮT}

Mục tiêu: Xác định các vi sinh vật gây bệnh gây viêm phổi ở trẻ từ 2 tháng đến 5 tuổi tại Bệnh viện Trung ương Thái Nguyên. Đối tượng và phương pháp nghiên cứu: Thực hiện trên 197 bệnh nhi từ 2 tháng đến 5 tuổi được chẩn đoán viêm phổi tại Bệnh viện Trung ương Thái Nguyên từ tháng 7/2020 6/2021 từ phân lập dịch tỵ hầu. Nghiên cứu mô tả cắt ngang. Kêt quả: Căn nguyên vi khuẩn thường hay gặp nhất ở các nhóm tuối chiếm tỉ lệ cão $86.3 \%$, sau đó đến virus, ít gặp nhất là đồng nhiễm virus và vi khuẩn chiếm tỷ lệ lân lượt là $9.1 \%$ và $4.6 \%$. Cụ thể trong 179 vi khuẩn được định danh. Vi khuẩn thường gặp là S.pneumonia (55.3\%), H.influenzae (23.5\%), M.catarhalis (15.1\%). Trong 27 bệnh nhân xác định được nguyên nhân do virus, virus RSV $(77.8 \%)$, cúm A, B chiếm (22.2\%). Kết luâan: Vi khuẩn thường gặp gây viêm phổi từ 2 tháng đển 5 tuổi là S.pneumonia và $H$.influenzae và M.Catarhalis. Virus gây viêm phổi thường gặp là RSV, cúm $A, B$. Trong 27 vius phân lập được RSV chiếm tỳ lệ cao (66.7\%) gây viêm phổi ở nhóm từ $2-12$ tháng.

Tư khóa: Căn nguyên, vi sinh vật, viêm phổi

\section{SUMMARY}

MICROBIOLOGY CAUSE PNEUMONIA IN

CHILDREN 2 MONTHS TO 5 YEARS OLD AT

THAI NGUYEN CENTRAL HOSPITAL

Objective: Identify microorganisms causing pneumonia in children from 2 months to 5 years old at Thai Nguyen Central Hospital. Subjects and research methods: 197 pediatric patients from 2 months to 5 years of age who were diagnosed with pneumoniae at Thai Nguyen Central Hospital from July 2020 to June 2021 with pharyngeal displacement analysis. Descriptive cross-sectional study. Results: The most common bacterial bases in the high proportion of groups are $86.3 \%$, followed by viruses, at least with viral and bacterial co-infections using the ratio of $86.3 \%$, respectively. $9.1 \%$ and $4.6 \%$. Specifically in 179 identified bacteria. Common bacteria are S.pneumonia $(55.3 \%)$, H.influenzae (23.5\%), M.catarhalis (15.1\%). In 27 patients with identified viral cause, RSV virus $(77.8 \%), A$, B accounted for (22.2\%). Conclusion: Bacteria commonly causing pneumonia from 2 months to 5 years old are S.pneumonia and H.influenzae and M.Catarhalis. The most common pneumonia cause viruses are RSV, A, B. In the 27 parsed viruses used

*Trường Đại học Y Dược Thái Nguyên

Chịu trách nhiệm chính: Đỗ Ngọc Quỳnh

Email: drquynhpt93@gmail.com

Ngày nhận bài: 8.6.2021

Ngày phản biên khoa họ: 3.8 .2021

Ngày duyệt bài: 12.8.2021

\section{Đỗ Ngọc Quỳnh*, Nguyễn Thành Trung*}

by RSV, a high rate $(66.7 \%)$ caused pneumonia in the group from 2 to 12 months.

Key words: etiology, microbiology, pneumonia.

\section{I. ĐĂT VẤN ĐỀ}

Viêm phổi là nguyên nhân tử vong hàng đâu ở trẻ em dưới 5 tuổi. Năm 2017, Tổ chức Y tế Thế giới báo cáo viêm phổi gây tử vong 808.694 trẻ, chiếm $15 \%$ tất cả các nguyên nhân gây tử vong ở trẻ dưới 5 tuổi trên toàn câu [8]. Nguyên nhân gây viêm phổi trẻ em có rất nhiều như vi khuẩn, virus, nấm... Các vi khuẩn gây bệnh chính là Streptococcus pneumonia, Heamaphilus influenza và Mycoplasma pneumonia và các virus gây viêm phổi ở trẻ em hay gặp là virus hợp bào hô hấp (RSV), Adenovirus, Rhinovirus. Hiện nay vi khuẩn không ngừng biến đổi, làm tăng khả năng kháng thuốc gây ra nhiêu khó khăn trong việc điều trị. Làm ảnh hưởng tới sức khỏe và sự phát triển của trẻ. Đã có rất nhiêuu trường hợp viêm phổi nặng diễn biến phức tạp phải nằm điều trị lâu. Điều đó ảnh hưởng đến kinh tế, tổn thất cho gia đình về tiền của và thời gian. Xác định được căn nguyên gây viêm phổi không những hạ thấp được tỷ lệ tử vong, mà còn giúp thây thuốc lựa chọn đúng thuốc trong thuốc giúp giảm thiểu việc kháng kháng sinh. Vî̀ vậy để tìm hiểu căn nguyên vi sinh vật gây viêm phổi ở trẻ từ 2 tháng đến 5 tuổi, chúng tôi tiến hành nghiên cứu đề tài này với mục tiêu: Xác định căn nguyên vi sinh vật gây viêm phổi ở tré tư 2 tháng đên 5 tuôi tại Bệnh viện Trung ương Thái Nguyên tháng 7/2020 - 6/2021.

\section{II. ĐỐI TƯỢNG VÀ PHƯƠNG PHÁP NGHIÊN CứU}

2.1. Đối tượng nghiên cứu. Trẻ từ 2 tháng đến 5 tuổi được chẩn đoán viêm phổi có xác định được nguyên nhân vi sinh vật vào điều trị tại trung tâm Nhi khoa Bệnh viện Trung ương Thái Nguyên.

\subsection{Tiêu chuẩn lựa chọn}

*Được chẩn đoán xác định là viêm phổi: Theo phác đồ bô Y tế năm 2015.

- Ho, sốt kèm theo ít nhất một dấu hiệu sau:

- Thở nhanh:

Dưới 2 tháng $\geq 60$ nhịp/phút.

Từ 2 tháng đến 12 tháng $\geq 50$ nhịp/phút.

Từ 12 tháng đến 5 tuổi $\geq 40$ nhịp/phút.

- Rút lõm lồng ngực (Phân dưới lồng ngực Iõm vào ở thì hít vào) 
- Nghe phổi có tiếng bất thường: Ran ẩm nhỏ hạt, ran nổ, ran phế quản, giảm thông khí khu trú.

- Xác định được căn nguyên vi sinh vật gây viêm phổi bằng nuôi cấy và định danh vi khuẩn qua dịch tỵ hầu tại Khoa Vi sinh bệnh viện Trung ương Thái Nguyên.

- Gia đình đồng ý tham gia nghiên cứu.

2.3. Thiết kế nghiên cứu: Mô tả cắt ngang.

2.4. Cõ̃ mẫu và phương pháp chọn mẫu

- Cõ mẫu: Áp dụng công thức tính cỡ mẫu ước tính một tỷ lệ trong quần thể nghiên cứu:

$$
\mathrm{n}=Z_{1-\frac{\alpha}{2}}^{2} \frac{p \cdot(1-p)}{d^{2}}
$$

III. KẾT QUẢ NGHIÊN CỨU

\section{1. Đặc điểm chung của đối tượng nghiên cứu}

Bảng 1: Viêm phổi của tré em phân theo tuổi, giới

\begin{tabular}{|c|c|c|c|c|c|c|c|c|}
\hline \multirow{2}{*}{ Giới tính } & $\mathbf{2 ~ - 1 2}$ tháng & \multicolumn{2}{|c|}{$\mathbf{1 3}-\mathbf{3 6}$ tháng } & \multicolumn{2}{|c|}{$\mathbf{3 7 - 6 0}$ tháng } & \multicolumn{2}{c|}{ Tống } \\
\cline { 2 - 9 } & $\mathbf{S L}$ & $\mathbf{\%}$ & $\mathbf{S L}$ & $\mathbf{\%}$ & $\mathbf{S L}$ & $\mathbf{\%}$ & $\mathbf{S L}$ & $\mathbf{\%}$ \\
\hline Nam & 57 & 28.9 & 48 & 24.4 & 9 & 4.6 & 114 & 57.9 \\
\hline Nữ & 35 & 17.8 & 41 & 20.8 & 7 & 3.5 & 83 & 42.1 \\
\hline Tống & $\mathbf{9 2}$ & $\mathbf{4 6 . 7}$ & $\mathbf{8 9}$ & $\mathbf{4 5 . 2}$ & $\mathbf{1 6}$ & $\mathbf{8 . 1}$ & $\mathbf{1 9 7}$ & $\mathbf{1 0 0}$ \\
\hline
\end{tabular}

Nhân xét: Trong 197 bênh nhi viêm phổi đủ tiêu chuẩn đưa vào nghiên cứu. Tuổi: Hầu hết các bệnh nhân thuộc lứa tuổi nhũ nhi (92/197 chiếm 46.7\%), tỷ lệ nam/nữ = 114/83=1.37/1.

3.2. Căn nguyên vi sinh vật gây viêm phổi của trẻ từ 2 tháng đến 5 tuoổi

Bảng 2. Tỷ lệ phân lập được các loại vi khuẩn trong dịch ty hầu

\begin{tabular}{|c|c|c|}
\hline Vi khuấn & Số lượng & Tỷ lệ (\%) \\
\hline S.pneumoniae & 99 & $55.3 \%$ \\
\hline H. influenzae & 42 & $23.4 \%$ \\
\hline M. catarrhalis & 27 & $15.1 \%$ \\
\hline S.aureus & 8 & $4.5 \%$ \\
\hline Khác & 3 & $1.7 \%$ \\
\hline Tống & $\mathbf{1 7 9}$ & $\mathbf{1 0 0}$ \\
\hline
\end{tabular}

Với $p=0.108$ của Đỗ Thi Thanh Xuân. Cõ mẫu nghiên cứu thu được tối thiểu 148 bệnh nhân và trên thực tế nghiên cứu trên 197 bệnh nhi chẩn đoán viêm phổi có xét nghiệm dịch ty. hầu và các xét nghiệm tìm căn nguyên gây bệnh.

2.5. Thu thập số liệu. Thông tin được thu thập qua bệnh án, phỏng vấn cha mẹ người nuôi dưỡng trẻ theo mâu nghiên cứu thống nhất.

2.6. Xử lý số liệu: Bằng phương pháp thống kê y học, sử dụng phần mềm SPSS 20.0.

2.7. Đạo đức nghiên cứu: Đề tài được thông qua bởi Hội đồng $Y$ sinh học trường Đại học Y dược Thái Nguyên.

Bảng 4. Tỷ lệ vi khuẩn gây viêm phổi theo tuổi

\begin{tabular}{|c|c|c|c|c|c|c|c|c|}
\hline \multirow{2}{*}{ Vi khuẩn } & \multicolumn{2}{c|}{$\mathbf{2 ~ - 1 2 \text { tháng }}$} & \multicolumn{2}{c|}{$\mathbf{1 2}-\mathbf{3 6 t h a ́ n g}$} & \multicolumn{2}{|c|}{ 37- 60tháng } & \multicolumn{2}{c|}{ Tống } \\
\cline { 2 - 9 } & $\mathbf{S L}$ & $\mathbf{\%}$ & $\mathbf{S L}$ & $\mathbf{\%}$ & $\mathbf{S L}$ & $\mathbf{\%}$ & $\mathbf{S L}$ & $\mathbf{\%}$ \\
\hline S.pneumoniae & 44 & 24.6 & 47 & 26.3 & 8 & 4.5 & 99 & 55.3 \\
\hline H. influenzae & 19 & 10 & 20 & 11.2 & 3 & 1.7 & 42 & 23.5 \\
\hline M. catarrhalis & 10 & 5.6 & 15 & 8.4 & 2 & 1.1 & 27 & 15.1 \\
\hline S. aureus & 4 & 2.2 & 3 & 1.7 & 1 & 0.6 & 8 & 4.5 \\
\hline Khác & 1 & 0.6 & 2 & 1.1 & 0 & 0 & 3 & 1.7 \\
\hline Tống & $\mathbf{7 8}$ & $\mathbf{4 3 . 6}$ & $\mathbf{8 7}$ & $\mathbf{4 8 . 6}$ & $\mathbf{1 4}$ & $\mathbf{7 . 8}$ & $\mathbf{1 7 9}$ & $\mathbf{1 0 0}$ \\
\hline
\end{tabular}

Nhận xét: S.pneumoniae, H.influenzae, M.catarrhalis là những khuẩn gặp hàng đầu ở các lứa tuổi gây ra tình trang viêm phổi ở trẻ em.

Bảng 5. Tỷ lể virus gây viêm phổi theo nhóm tuổi

\begin{tabular}{|c|c|c|c|c|c|c|c|c|}
\hline \multirow{2}{*}{ Virus Tuối } & \multicolumn{2}{|c|}{$\mathbf{2}-\mathbf{1 2 t h a ́ n g}$} & \multicolumn{2}{|c|}{$\mathbf{1 2}$ - 36tháng } & \multicolumn{2}{|c|}{ 37- 60tháng } & \multicolumn{2}{c|}{ Tống } \\
\cline { 2 - 9 } & $\mathbf{S L}$ & $\mathbf{\%}$ & $\mathbf{S L}$ & $\mathbf{\%}$ & $\mathbf{S L}$ & $\mathbf{\%}$ & $\mathbf{S L}$ & $\mathbf{\%}$ \\
\hline RSV & 18 & 66.7 & 3 & 11.1 & 0 & 0 & 21 & 77.8 \\
\hline Cúm A,B & 0 & 0 & 3 & 11.1 & 3 & 11.1 & 6 & 22.2 \\
\hline Tống & $\mathbf{1 8}$ & $\mathbf{6 6 . 7}$ & $\mathbf{6}$ & $\mathbf{2 2 . 2}$ & $\mathbf{3}$ & $\mathbf{1 1 . 1}$ & $\mathbf{2 7}$ & $\mathbf{1 0 0}$ \\
\hline
\end{tabular}

Nhận xét: Căn nguyên virus RSV thường gặp ở lứa tuối < 36 tháng chiếm tỉ lệ cao. 
Bảng 6: Căn nguyên vi khuẩn gây bệhh theo mức độ

\begin{tabular}{|c|c|c|c|c|c|c|}
\hline \multirow{2}{*}{ Vi khuẩn đửc độ } & \multicolumn{2}{|c|}{ Viêm phổi } & \multicolumn{2}{c|}{ Viêm phối nặng } & \multicolumn{2}{c|}{ Tống } \\
\cline { 2 - 7 } & $\mathbf{S L}$ & $\mathbf{\%}$ & $\mathbf{S L}$ & $\mathbf{\%}$ & $\mathbf{S L}$ & $\mathbf{\%}$ \\
\hline S.pneumoniae & 87 & 48.6 & 12 & 6.7 & 95 & 55.3 \\
\hline H. influenzae & 35 & 19.6 & 7 & 3.9 & 42 & 23.5 \\
\hline M. catarrhalis & 21 & 11.7 & 6 & 3.4 & 27 & 15.1 \\
\hline S.aureus & 3 & 1.7 & 5 & 2.8 & 8 & 4.5 \\
\hline Khác & 1 & 0.6 & 2 & 1.1 & 3 & 1.7 \\
\hline Tống & $\mathbf{1 4 7}$ & $\mathbf{8 2 . 1}$ & $\mathbf{3 2}$ & $\mathbf{1 7 . 9}$ & $\mathbf{1 7 9}$ & $\mathbf{1 0 0}$ \\
\hline
\end{tabular}

Nhận xét: - S.pneumoniae, H.influenzae, M.catarrhalis chủ yếu gây ra viêm phối.

- S.aureus chủ yếu gây ra viêm phổi nặng. S.pneumoniae gây viêm phổi cao hơn so với viêm phổi nặng.

\section{BÀN LUÂN}

4.1. Tỷ lệ phân lập được các vi khuẩn ở trẻ viêm phổi. 197 trường hợp bệnh nhi viêm phổi từ 2 tháng đến 5 tuổi phân lập được vi khuẩn tại Bệnh viện trung ương Thái Nguyển tỷ lệ trai là $59.7 \%$ cao hơn 1,4 lần so với tỷ lệ bệnh nhân gái là $42.1 \%$. Độ tuổi có tỷ lệ mắc viêm phổi cao nhất là từ $2-12$ tháng. Căn nguyên chiếm tỷ lệ cao nhất là S.pneumonia (50.3\%), tiếp đến là $H$.influenzae,,$M$.Catarhalis, S.aureus với tỷ lệ tương ứng $21.3 \%, 15.1 \%, 4.5 \%$. Kết quả của chúng tôi phù hợp với nghiên cứu của Lưu Thị Thùy Dương (2019) với vi khuẩn gây viêm phổi chiếm tỷ lệ cao nhất là S.pneumoniae $55,8 \%$, tiếp đến là H.influenza $23,2 \%$ [1]. Kết quả có sự tương đồng với tác giả Nguyễn Văn Đếm (2020) ba căn nguyên hay gặp nhất là H.influenza, S.pneumoniae, M.catarrhalis với tỉ lệ tương ứng là $48.7 \%, 27.8 \%, 18 \%$. Cùng với kết quả của Nguyễn Thị Hà (2020) nguyên nhân thường gặp nhất gây viêm phổi cộng đồng là H.Influenzae (52.4\%), tiếp theo là S.pneumoniae chiếm $(33.7 \%)$ [2]. Các nghiên cứu trên thế giới khác như ở Ân Độ Joseph L. Mathew cùng cộng sự thấy tỷ lệ Streptococcus pneumonia chiếm (79.1\%) chiếm ưu thế, tiếp theo là Haemophilus pneumonia $(9,6 \%)$ [5]. Theo nghiên cứu bệnh chứng đa trung tâm của mạng lưới GABRIEL từ 2010 - 2014 ở các nước Campuchia, Trung Quốc, Haiti, Ấn Độ, Madagascar, Mali, Mông Cổ và Paraguay thấy tỉ lệ S.pneumoniae chiếm $42,2 \%$ chiếm tỷ lệ cao nhất [6]. Nguyên nhân vi khuẩn gây viêm phổi ở các nghiên cứu có sự khác biệt về tỷ lệ phân bố, có thể do yếu tố mổi trường ở từng vùng địa lý có sự khác biệt ở khu vực Đông Nam Á nhiệt đới nóng ẩm. Xong căn nguyên vi khuẩn gây viêm phổi chiếm tỉ lệ cao vấn là: Streptococcus pneumonia và Haemophilus pneumonia.

Kết quả nghiên cứu của chúng tôi về tỷ lệ virus gây viêm phổi phù hợp với kết quả nghiên cứu của tác giả Lê Văn Tráng (2016) về tác nhân gây viêm phổi các loại virus là $34.2 \%$, có 51 trường hợp dương tính với virus và nấm, cao nhất là virus RSV chiếm $27.4 \%[4]$. Tuy nhiên cũng có sự khác biệt với kết quả của Phạm Thị Thanh Tâm về tỷ lệ nhiễm virus RSV là $8.4 \%$ trong viêm phổi tái diễn có suy hô hấp [3]. Theo nghiên cứu của Wesley $\mathrm{H}$ và cộng sự với 572 trẻ mắc viêm phổi cộng đồng do virus: RSV là phổ biến nhất $(26,6 \%)$, tiếp theo là hRV $(21,9 \%)$ và hMPV $(15,1 \%)[7]$. Như vậy, virus RSV là căn nguyên gây viêm phổi cộng đồng chính ở trẻ. Căn nguyên virus giúp cho thầy thuốc trong việc chẩn đoán và điều trị có hiệu quả cho trẻ bị viêm phổi.

Phân bố tỷ lệ các vi khuẩn gây viêm phổi cho thây nhóm trẻ từ 2-12 tháng, vi khuẩn gặp hàng đầu là S.pneumonia chiếm $24.6 \%$, thứ 2 là H.influenzae chiếm $10 \%$, tiếp đến là M.catarrhalis với 5.6\%; nhóm trẻ từ 12 - 36 tháng tuổi vi khuẩn chiếm tỷ lệ cao nhất là S.pneumonia $26.3 \%$, tiếp đến là $H$.influenzae $11.2 \%$ cuối cùng là M.cartarrhalis: $5.6 \%$. Chúng tôi nhận thấy vi khuẩn S.pneumoniae và H.influenzae có xu hướng gây bệnh ở mọi lứa tuổi. Kết quả nghiên cứu của chúng tôi có những điểm tương đồng với nghiên cứu của tác giả Quách Ngọc Ngân với trẻ từ 2 tháng tuổi vi khuẩn thường gặp là S.aureus, S.pneumonia, H.influenzae, M.Catarrhalis. Với nhóm trẻ từ 12 tháng đến 5 tuổi vi khuẩn thường gặp là S.pneumonia, H.influenzae, M.Catarrhalis. Căn nguyên virus RSV thường gặp ở lứa tuổi < 36 tháng chiếm tỉ lệ cao, đặc biệt ở nhóm tuổi từ 2 12 tháng chiếm $66.7 \%$

\section{KẾT LUẬN}

1.Căn nguyên vi khuẩn thường hay gặp nhất ở các nhóm tuổi, sau đó đến virus, ít gặp nhất là đồng nhiễm virus và vi khuẩn chiếm tỷ lệ lần lượt là $86.3 \%, 9.1 \%, 4.6 \%$ ở trẻ từ 2 tháng -5 tuổi. Đặc biệt là lứa tuổi < 36 tháng trẻ bị viêm phổi do vi khuẩn chiếm tỷ lệ cao.

2. Các vi khuẩn gây viêm phổi ở trẻ từ 2 tháng đến 5 tuổi tại Bệnh viện Trung ương Thái Nguyên thường gặp là S.pneumonia (55.3\%), 
H.influenzae (23.5\%), M.catarrhalis (15.1\%). Đặc biệt S.pneumonia là vi khuẩn gây bệnh ở mọi nhóm tuổi chiếm tỉ lệ cao.

\section{TÀI LIÊU THAM KHẢO}

1. Lưu Thị Thùy Dương (2019), Đăc điểm lâm sàng, cận lâm sàng và một số yếu tố liên quan đến mức độ nặng của viêm phổi ở trẻ từ 2 - 36 tháng tại bệnh viện Trung ương Thái Nguyên, Luận văn bác sỹ̃nội trú, Đaii học Y Dược Thái Nguyên.

2. Nguyễn Thị Hà, Đoàn Mái Thanh và Nguyễn Thi Yến (2020), "Đắc điểm lâm sàng và căn nguyên gây viêm phổi cộng đồng tại Khoa Quốc tế Bệnh viện Nhi Trung Ương", Tạp chí nghiên cứu Y hoc. 131(7), tr. 67-73.

3. Phạm Thị Thanh Tâm và Lê Thanh Hải Phùng Thị Bích Thủy (2021), "Tỷ lệ nhiễm một số vì khuẩn, virus ở trẻ viêm phổi tái diễn có suy hô hấp tai Bệnh viện Nhi Trung ương", Tạp chí Nghiên cứu và Thực hành Nhi khoa. 5(1).

4. Lê Văn Tráng (2016), "Nghiên cứu căn nguyên gây bệnh và yếu tố nguy cơ ở trẻ em bị viêm phổi kéo dải trên 2 tuần tai khoa hô hấp bệnh viên Nhi Thanh Hóa ", Tap chí Nghiên cứu và Thực hành Nhi khoa, tr. 58-64.

5. Mathew JL, Singhi S. Ray $P$ và et al (2015), "Etiology of community acquired pneumonia among children in India: prospective, cohort study", Journal of global health. 5(2).

6. Benet T., Sanchez P.V. Messaoudi M. và et al (2017), "Microorganisms Associated With Pneumonia in Children $<5$ Years of Age in Developing and Emerging Countries: The GABRIEL Pneumonia Multicenter, Prospective, Case-Control Study", Clin Infect Dis. 65(4), tr. 604-612.

7. Self $W$. H, Williams D. J. Zhu $Y$. và et al (2016), "Respiratory Viral Detection in Children and Adults: Comparing Asymptomatic Controls and Patients With Community-Acquired Pneumonia. ", J Infect Dis 2016, tr. 213 - 584.

8. WorldHealth Organization (2019), "Pneumonia" https://www.who.int/en/news-room/factsheets/detail/pneumonia

\section{NGHIÊN CỨU ĐĂC ĐIỂM GIẢI PHẪU BỆNH U LYMPHO TẾ BÀO B XÂM NHẬP TỦY XƯƠ'NG}

\section{TÓM TẮT}

Đă̆t vấn đề: Đánh giá tình trạng tủy xương đóng vai trò quan trọng trong phân chia giai đoạn u lympho, giúp tiên lượng cũng như lựa chọn phương pháp điêu trị. Muc tiêu: Khảo sát tỉ lệ và đăc điểm mô học tủy xương các trường hợp u lympho tế bào $B$ xâm nhập tủy xương. Đối tượng và phương pháp: Nghiên cứu mô tả cắt ngang các trường hợp u lympho tế bào $B$ tại Bệnh viện Truyền máu Huyết học từ tháng 01/2019 đến tháng 12/2020. Kết quả: Tỉ lệ u lympho tế bào $\mathrm{B}$ xâm nhâp tủy xương là $64,8 \%$. 40\% trướng hợp u lympho tế bào $B$ độ ác cao và $80 \%$ trường hợp u lympho tế bào $B$ độ ác thấp xâm nhập tủy xương. $\mathrm{LPL}$ và $\mathrm{BL}$ có tỉ lệ xâm nhập tủy xương cao nhất $(100 \%)$, thấp nhất là $\operatorname{DLBCL}(25,6 \%)$. Hình thái xâm nhập thường gặp nhất là dạng lan tỏa $(53 \%)$, tiếp theo là dạng hôn hợp (31\%). Dạng cạnh bè xương ghi nhận trong $50 \%$ FL và $10 \%$ DLBCL (FL chuyển dạng DLBCL). Dạng trong mạch máu trong xoang 0\%. 72,2\% MZL xâm nhập kiểu hỗn hợp. Kết luận: U lympho tế bào $B$ độ ác thấp có tỉ lệ xâm nhập tủy xương cao hơn u lympho tế bào $B$ đô ác cao. Hình thái xâm nhập tủy xương thường gặp nhất là dạng lan tỏa.

Tư khóa: U lympho tế bào $B$, dạng canh bè xương, dạng khu trú ngẫu nhiên, dạng mô kẽ், dạng trong mạch máu trong xoang, dạng hỗn hợp.

*Bệnh viện Truyền máu - Huyết học

**Đại học Y dược Thành phố Hồ Chí Minh

Chịu trách nhiệm chính: Tiêu Ngọc Kim Ngân

Email: kimnganbth1994@gmail.com

Ngày nhân bài: 4.6.2021

Ngày phản biên khoa hoc: 2.8.2021

Ngày duyệt bài: 11.8.2021

\section{SUMMARY \\ THE CHARACTTERISTICS OF B-CELL LYMPHOMAS INVOLVEMENT IN THE BONE MARROW}

Introduction: Bone marrow examination is an integral part of the clinical staging of lymphoma, also prognosis and therapeutic strategies. Objective: This study aimed to evaluate the incidence and characteristics of bone marrow involvement of B-cell lymphoma on trephine biopsy. Subjects and Methods: Cross section description of B-cell lymphoma from January 2019 to December 2020 at Blood Transfusion Hematology Hospital. The incidence and pattern of bone marrow involvement were analyzed. Results: The frequency of bone marrow involvement of B-cell lymphomas was $64.8 \%$. Bone marrow involvement was present in $80 \%$ of low-grade B-cell lymphomas, and $40 \%$ of high-grade variants. The highest incidence of bone marrow involvement was seen in $\mathrm{LPL}$ and $\mathrm{BL}(100 \%)$ and the lowest was found in DLBCL (25.6\%). Diffused pattern of infiltration was predominant (53\%), followed by mixed pattern (31\%). Typical bone marrow involvement in $50 \% \mathrm{FL}$ and $10 \%$ DLBCL (transformed FL to DLBCL) was characterized by paratrabecular infiltration. Intrasinusoidal infiltration was not detected. The most frequent pattern was mixed pattern $(72.2 \%)$ found in MZL. Conclusion: The frequency of bone marrow involvement of low-grade B-cell lymphomas was higher than high-grade variants. The pattern of diffuse infiltration was predominantly. Keywords: B-cell lymphoma, paratrabecular infiltration, random focal infiltration, diffuse infiltration, interstitial infiltration, intrasinusoidal infiltration, mixed infiltration 